\title{
Smartphones and Location Awareness in Brazil: Users' Reactions ${ }^{1}$
}

\author{
Ana Maria Nicolaci-da-Costa ${ }^{2}$ \\ Mariana Santiago de Matos-Silva \\ Pontificia Universidade Católica do Rio de Janeiro, Rio de Janeiro-RJ, Brazil
}

\begin{abstract}
The general objective of this study was to gain detailed information on how Brazilians are using the many features of their smartphones according to their own accounts. Among these features, of particular interest were the ways in which they react to and deal with the novelty presented by location awareness, especially in LBSN applications. A qualitative research guided by the Underlying Discourse Unveiling Method (UDUM) was carried out. Fifteen knowledgeable users of digital technologies aged between 23 and 38 were recruited in Rio de Janeiro and São Paulo. Open-ended-question interviews were conducted with each. Results revealed that location-sharing reinforced their pre-existing fears related to violence and criminality. They knew that criminals may have access to these technologies. Therefore, in order to protect their personal safety most participants avoided location-disclosure. The fears mentioned by them are embedded in the violent context they live in.
\end{abstract}

Keywords: Internet, communication and technology, fear, violence

\section{Smartphones e Recursos Locativos no Brasil: Reações de Usuários}

\begin{abstract}
Resumo: Este estudo teve o objetivo geral obter informações detalhadas sobre a maneira como brasileiros estão usando os diversos recursos de seus smartphones. Seu interesse específico foi entender como os usuários reagem à novidade da geolocalização presente em redes sociais locativas (RSLs) e como com ela lidam. Foi realizada uma pesquisa qualitativa guiada pelo Método de Explicitação do Discurso Subjacente (MEDS). Quinze usuários assíduos de tecnologias digitais, com idades entre 23 e 38 anos, foram recrutados no Rio de Janeiro e em São Paulo. Todos participaram de entrevistas individuais com perguntas abertas. Os resultados revelaram que o compartilhamento da própria localização reforçava medos preexistentes relacionados à violência e à criminalidade. Os participantes sabiam que criminosos podem ter acesso a estas tecnologias e, para proteger sua segurança, a maioria evitava divulgar sua localização. Os medos por eles mencionados têm raízes na realidade violenta em que vivem.
\end{abstract}

Palavras-chave: Internet (rede de computador), comunicação e tecnologia, medo, violência

\section{Smartphones y Recursos Locativos en Brasil: Reacciones de Usuarios}

\begin{abstract}
Resumen: El objetivo general del estudio fue obtener informaciones detalladas acerca de cómo los brasileños están utilizando los diversos recursos de sus teléfonos inteligentes. Su particular interés era comprender cómo los usuarios reaccionan ante la novedad de la geo-localización presente en las redes sociales locativas (RSL) y como tratan con ella. Se llevó a cabo una investigación con el Método de Explicación del discurso Subyacente (MEDS). Quince usuarios frecuentes de las tecnologías digitales, entre 23 y 38 años, fueron reclutados en Rio de Janeiro y São Paulo. Todos participaron de entrevistas individuales con preguntas abiertas. Los resultados revelaron que la participación de la propia ubicación reforzó los temores en relación a la violencia y criminalidad. Los participantes estaban conscientes de que los criminales pueden tener acceso a estas tecnologías y, para proteger su seguridad, la mayoría evitó revelar su ubicación. Los temores mencionados tienen sus raíces en la realidad violenta en la que viven.
\end{abstract}

Palabras clave: Internet, comunicación y tecnología, miedo, violencia

Throughout history, new inventions which produced radical changes in one or another aspect of people's ways of living have aroused different imaginary fears and frequent strong reactions. To name just a few, it was thought that writing would create loss of memory (Baym, 2010), the printing press would kill images (Eco, 1996) and the mechanization of labor would lead to the substitution of men for machines (Nisbet, 1966).

Telecommunication technologies have not escaped this fate. The invention of the telephone is paradigmatic. In an analysis of the first impacts the telephone had on the American people, Fischer (1992) writes that this new

\footnotetext{
${ }^{1}$ Support: National Council for Scientific and Technological Development (CNPq).

2 Correspondence address:

Ana Maria Nicolaci-da-Costa. Departamento de Psicologia da Pontifícia Universidade Católica do Rio de Janeiro. Rua Marquês de São Vicente, 225, Gávea. CEP 22543-900. Rio de Janeiro-RJ, Brazil. E-mail: anicol@puc-rio.br
}

type of communication with distant others was seen as "sustain[ing] only a semblance of 'real relations"” (Fischer, 1992, p. 224). It was feared it could replace face-to-face relations and undermine neighborhood solidarity.

As far as these old technologies are concerned, history has made it clear that such negative reactions - known as dystopian - were triggered by fantasized threats and dangers mostly related to people's resistance to change and not to real negative consequences. Even so, it seems fears of the new do not subside. They tend to accompany the emergence of most novel inventions as is the case of contemporary communication technologies.

\section{Reactions to Contemporary Telecommunication Technologies}

The Internet. Much in the same way as the telephone, the Internet introduced a new paradigm for acquiring information 
and communicating with others in millions of people's lives. This resulted in innumerable fears, which soon took the form of an intense and widespread paranoid commotion for which American psychologists - Greenfield (1999), Kraut et al. (1998), Young (1998) - were to a great extent responsible. Pathological behaviors such as the so-called "Internet addiction", alienation, isolation from others, depression and the like were promptly identified by them.

The power of these alleged dangers and fears created by the Internet manifested itself by crossing boundaries and contaminating public imagination in different places (Nicolaci-da-Costa, 2002). In Europe, for instance, a Commission with the specific purpose of investigating how to attenuate what was referred to as the "devastating" effects of the Internet was appointed by the European Community (Castells, 2003). In Brazil, the contamination of the media, and consequently of popular imaginary, was very strong. Based on the "alarming" results of international investigations, Brazilian newspapers and magazines were particularly keen on disseminating the "discovery" of Internet addiction (Nicolaci-da-Costa, 2002). Brazilian academic circles did not go untouched (Nicolaci-da-Costa, 2005). Dystopian views penetrated them mainly when reinforced by the negative discourses of highly qualified sociologists such as Bauman (2003) and Sennett (1998).

Cell and smartphones. Cell phones are the exception that confirms the rule. In the early days of their diffusion, they were almost exclusively used to make and receive calls or to send and receive texted messages. One could call/text people while on the move and without knowing the recipients' whereabouts. These advances however were perceived just as a development of the cordless landline phone, not as radically new (de Gournay, 2002; Kim, 2002).

The fact is that cell phone sociability was very similar to that people had been used to for decades. In different parts of the world, including Brazil, besides family members, this sociability involved only friends and acquaintances made in the "real" world (Katz \& Aakhus, 2002; Ling, 2004; Nicolaci-da-Costa, 2005). At that time cell phones did not foster encounters between strangers (Nicolaci-da-Costa, 2004) as the Internet did and, hence, aroused no fears.

The same cannot be said about smartphones. The latter are mobile phones which combine the functions earlier performed by several well-known devices, such as digital cameras, video and voice recorders. They also allow access to the Internet and, through their thousands of applications (Souza e Silva \& Frith, 2012), to many other activities earlier carried out on computers. If this was all, they could just be seen as assembling and expanding widely accepted technologies. Therefore, they should pose no threats. This is not the case, however, because they introduce a very sensitive novelty: location awareness.

Most of the functions performed through applications on smartphones can be associated to GPS and other location services. Hence, these devices and their users can be located in the "real" world with varying degrees of precision (Consolvo et al., 2005) and for different purposes, such as to provide locationbased services (LBS). Some of these applications, for instance, provide users with maps in which their location is identified and also with navigation facilities that help them get around. Other applications may use the device's location to gather information about points of interest in the users' vicinity.

There are also applications which allow access to locationbased social networks (LBSNs) whose users can locate each other when they make check-ins in the places they go to. Thus, on a typical day, a user can make check-ins at work, at home and also in public places. This obviously means that other members of the same LBSN will be able to track his/her movements and may get to know his/her habits if the same check-ins are made frequently. As it should be expected, location awareness has brought about new fears. There are, however, important differences between reactions to LBS and LBSNs.

LBS (such as navigation and mapping) have not met much resistance and, almost everywhere including Brazil, people seem to be comfortable using them. By comparison, LBSNs have a much lower number of users in most countries. To give just one example, recent statistics show that $74 \%$ of Americans use their smartphones to get location-based information, but only $18 \%$ of them are members of LBSNs (Zickuhr, 2012).

This lower number of LBSN users appears to be a consequence of the frights triggered by these networks, which, in reality, often only magnify fears and anxieties that already existed in different contexts before the diffusion of smartphones. In a number of countries (as the USA, Canada and the United Kingdom), these fears are usually related to issues regarding privacy, surveillance and control (Gordon \& Souza e Silva 2011; Souza e Silva \& Frith, 2012). Privacy issues seem to be the most important according to investigations conducted by Junglas and Watson (2008) and Tsai, Kelley, Cranor, and Sadeh (2010). Their results show participants thought that disclosing their own location could allow their privacy to be invaded both by other members of the same LBSN who could use such information for stalking (Souza e Silva \& Frith, 2012) and by companies which could use it for unsolicited advertising (Junglas \& Watson, 2008).

In the USA, another more powerful potential invader of privacy is feared: the American government itself. In fact, Junglas and Watson (2008) report that LBSNs users' location information has attracted the interest of US Federal law enforcement agencies for surveillance purposes. In such a context, a large share of the responsibility for the low adoption of location-sharing applications may be attributed to fear of privacy invasion. Benefits in the use of LBSNs do not outweigh it (Junglas \& Watson, 2008; Tsai et al., 2010). Government surveillance, however, does not necessarily generate fears. In Australia, for example, citizens prefer to trade off privacy for the security against terrorism they trust their government to provide (Michael, Perusco, \& Michael, 2006). Perceived 
dangers and risks are indeed different in different societies. Consequently, so are fears and reactions to them.

In Brazil, academic references to LBS and LBSNs in the human and social sciences are rare. The few publications on these topics (Lemos, 2009; Pellanda, 2011; Sousa \& Cunha, 2012; Zago \& Rebs, 2011) are usually circumscribed to the area of communication. Most of them are dedicated solely to theoretical discussions. Pellanda (2011), for instance, examines the connections between virtual and physical spaces promoted by Foursquare (a LBSN), while Sousa and Cunha (2012) use the same LBSN to consider the meaning of place.

Even scarcer than Brazilian studies of LBS and LBSNs are the academic references to the fears they raise. Lemos (2009) discusses the potential of locative media for surveillance and monitoring purposes, but he restricts himself almost exclusively to the discussion of international literature. Zago and Rebs (2011), on the other hand, report research results that suggest that the Brazilian users of Foursquare are not very worried about privacy.

Although there is little academic production, daily life informal observations strongly suggest that, in general, Brazilians do not exhibit the same fears as users of other countries reported in specialized literature. Governmental surveillance and invasion of privacy by individuals or companies do not seem to worry them. There is something, however, that Brazilians, mainly those who live in violent metropolises like Rio de Janeiro and São Paulo, are very much afraid of. They are afraid of criminality which can endanger their personal security. Whether this fear is transferred to their use of smartphones is one the issues a qualitative empirical study of Brazilians' use of these devices set out to investigate.

\section{An Empirical Study of Smartphone Use in Brazil}

In spite of the acute socioeconomic differences that divide its 192 million inhabitants, so far Brazil has revealed a relatively homogeneous scenario of use of digital information and communication technologies (DICTs). Most Brazilians have access to the Internet, even if not always by legal means (Souza e Silva, Sutko, Salis, \& Souza e Silva, 2011). Cell phones have also had a huge penetration. At present, the number of devices - 253 million - exceeds that of the Brazilian population ("Brasil já possui 253 milhões de celulares ativos", 2012).

As far as smartphones are concerned, however, the picture is very different mainly because they are still very expensive. In 2012, smartphone owners in Brazil reached the milestone of 27 million ("Our Mobile Planet", 2012), roughly $14 \%$ of the population. This is a rather small percentage of the population, but 27 million is by no means a small number. It is actually a number large enough to demand that researchers investigate how these devices and their locative capabilities are being appropriated in the context of Brazilian culture.

The general objective of this study was, therefore, to gain detailed information on how Brazilians are using the many features of their smartphones according to their own accounts. Among these features, of particular interest were the ways in which they react to and deal with the novelty presented by location awareness, especially in LBSN applications.

\section{Method}

The different stages of this study were carried out following the guidelines of the Underlying Discourse Unveiling Method, or, in Portuguese, Método de Explicitação do Discurso Subjacente (MEDS), deeloped by Nicolaci-daCosta (2007). This qualitative method was chosen because it has been very successful in making visible what lies behind explicit discourse. Participants are encouraged to disclose their opinions, feelings and behaviors when answering openended questions based on the topics under investigation.

\section{Participants}

The participants were recruited according to the following criteria: (a) they should be adults who had been smartphone users for a minimum of two months (so that they were familiar with the device's features); (b) interviewees should be between 20 and 40 years old (smartphone devices and mobile monthly plans are often inaccessible to the very young while older people are likely to ignore most smartphone applications); (c) all of them had to be Brazilians and live in Brazil; and (d) participants should be savvy users of new technologies. Given the high costs of a smartphone and of the services associated with it, participants would inevitably be members of the upper-income strata of Brazilian society.

Keeping the above criteria in mind, participants suggested by friends and acquaintances were contacted online. It is consensual in specialized literature (Maxwell, 2005; Nicolaci-da-Costa, 2007) that the in-depth characteristics of qualitative interviews and craft-like analysis performed on them require the use of a small number of participants. Therefore, a total of 15 people ( 6 women and 9 men) were interviewed. All belonged to the high-income strata of Brazilian society and had university degrees in a variety of areas such as architecture, psychology, design, law, computer sciences and communication. They were also eager users of new technologies, always keen on experimenting new ones. They had had their smartphones for a period that varied from 3 months to 3 years. All of them consented to being interviewed online (more details about their individual profiles will be provided in the results section). All participants were also told that their names would be changed for publication purposes and no content that could identify them would be disclosed.

\section{Instrument}

The only instrument used was the interview schedule. This schedule was divided in two parts. The first one was composed by objective questions about the participants, such as age, schooling, profession, occupation etc. The second 
consisted of items upon which the interviewer constructed in-context open-ended questions so that they would sound natural as in an informal conversation. It has been shown (Nicolaci-da-Costa, 2002, 2004) that the more informal the interview, the more the participants volunteer information about their feelings, opinions, habits and the like. These items were of a more subjective nature and contemplated topics related both to smartphone use in general and to location awareness. The items were: (a) Smartphone use: model owned; reasons for choosing that particular device/model; how long ago it had been purchased; preferred/most used applications, why?; and (b) Location awareness: awareness/unawareness of locative features and settings in the device being used; use of location-based services; advantages/disadvantages of using LBS; feelings about disclosing his/her own location; known LBSNs; reasons for using/not using LBSNs; friends' use of LBSNs; advantages/disadvantages of using LBSNs.

\section{Procedure}

Data collection. The data were collected by means of 15 individual interviews carried out on programs such as Windows Live Messenger and Facebook (Nicolaci-daCosta, Romão-Dias, \& Di Luccio, 2009). Being savvy users of the Internet, all interviewees felt very comfortable in those environments. Online interviews were also easier to fit in their schedules and allowed researchers to interview people who lived in different cities.

Data analysis. MEDS stipulates that data collected in the interviews should not be edited or altered in any way and should be analyzed in two different stages. In the first stage, the inter-participants one, the statements made by all interviewees in reply to each topic of the schedule are compared in search of recurrent ones. Once found, these are assembled in temporary categories of analysis. In the following stage, called intra-participants, all responses given by each interviewee are analyzed as an independent unit to check for inconsistencies or contradictions. When found, these inconsistencies and/or contradictions are grouped into new categories according to their meanings. Upon completion of these first two stages, the researcher returns to the inter-participants analysis in order to verify whether these inconsistencies/contradictions are idiosyncratic or also present in other interviewee's replies. Contradictions and inconsistencies are taken to lend visibility to the unconscious conflicting values inherent in any processes of change. The researcher can go back and forth between these two types of analysis as many times he/she deems necessary to apprehend the complexities of participants' discourse.

\section{Ethical Considerations}

The investigation was approved by the Ethical Committee of the Pontifícia Universidade Católica do Rio de Janeiro, under the protocol number 2012-12.

\section{Results}

\section{Degrees of Familiarity With Technologies in General}

As previously mentioned, 15 people ( 6 women and 9 men) were interviewed. Their ages ranged from 23 to 38. Most of them lived in Rio de Janeiro (RJ) and only two in São Paulo (SP). Even though one of the criteria for recruiting them was that they should be savvy users of new Technologies, how they reported to deal with the latter revealed that, on top of being savvy, they had different degrees of commitment to DICT's. Based on these findings, the participants were assigned to three different categories of users: (a) Experienced lay users (ELU): interviewees who, not being experts, were very competent in coping with the complexities of the several devices they own and their applications; (b) Professionals (PRO): participants whose occupations were directly linked to the DICTs such as systems analysts or journalists specialized in technology; and (c) Geeks (GK): enthusiastic users for whom the DICTs were a source of pleasure, a challenge or a "serious hobby" that makes them always keen on getting to know new devices/technologies and buying/ using them as soon as they are available.

\section{Results of the Inter-Participants' Analysis}

Use of LBS. All interviewees were well-acquainted with a host of LBS. The most popular among them were maps and navigation applications, such as Google Maps and Waze, which they used frequently when in unknown territory. Also appreciated by many were applications that provide information about bars and restaurants in one's vicinity (such as Foodspotting and Lunchbox). Some also employed applications which monitor physical exercises having the user's location as a reference (such as RunKeeper and Nike Plus). Irrespective of their preferences, all participants revealed to be very comfortable with LBS. They had already become part of their daily lives.

Use of LBSNs. In contrast to LBS, most LBSNs (such as Yelp and Gowalla) were unknown to the interviewed men and women. Foursquare (a network in which users "check in" at venues and are awarded points and badges for doing so) was the exception, but only four of the participants used it regularly. Three other interviewees made sporadic use of it while all the remaining ones - eight - did not use it at all at the time of the interviews (four of them had already done so but quit). Results will be presented separately for non-users and users.

Non-users. The majority of participants in this investigation were non-users of LBSNs. The main reason for this became apparent when it was verified that in each and every interview there were opinions similar to those of Marcos (36, PRO, systems analyst, RJ,), who thought that "on the one hand, Foursquare is interesting, but on the other it is dangerous...". Adriana (34, ELU, psychologist, RJ) agreed with Marcos and explained this shared position a bit more. Foursquare is interesting, she said, because one "can meet friends who are close by" and dangerous because it "exposes too much of your life by making the information about where you are and the places you 
go to public". Giovanna (26, GK, marketing professional, SP) revealed to perceive the same danger when she stated that, on Foursquare, "you are not only exposing where you are. You are exposing where you usually go, your routine".

Making one's own routine public is considered risky because this kind of information can end up in the "wrong hands". Débora (37, ELU, psychologist, RJ), for instance, declares that sharing one's own location can be a way of "allowing criminals to know where you are". Possession of such information could facilitate the perpetration of several crimes, such as home invasions and thefts. Luiza (38, ELU, architect, RJ) gives a hypothetical but plausible example: "Someone sees my address on Foursquare, comes here and tells the doorman: 'I want to see Luiza, but she said not to use the intercom (...) Then the doorman lets him in!". Flávio (38, GK, economist, RJ), on his turn, believes that knowing someone's routine may have even more serious consequences. It can make it easy to plan a kidnapping: "If someone [knows] where you work, where you live, your daily routine of work and leisure, he easily finds out where and when to act".

Besides these hypothetical fear-revealing examples, the interviewees also mentioned actual cases of crimes committed against those who shared their location online. André (38, GK, lawyer, RJ) made such a revelation: "I know people whose family members received those alarming phone calls of false kidnappings (...) because they were in the habit of making their location public". Eduardo (35, GK, marketing professional, SP) also reported an experience lived by one of his acquaintances, who "traveled to Europe and yelled it on the social networks". His house was broken into and the thief left a note asking him to always let people know when he traveled. Other participants, such as Flávio (38, GK, economist, RJ), heard about these and other similar crimes on the media: "The media have already reported the existence of gangs which specialize in discovering profiles of people who display wealth [on social networks] and make them their targets for robbery and other crimes".

These and other frequently reported cases led non-users to be fearful of sharing their own location. Their opinions were very similar in this respect. According to Luiza (38, ELU, architect, RJ), location sharing is something that "goes beyond the limits of reasonable exposition". Likewise, Débora (37, ELU, psychologist, RJ) said: "Human beings cannot overexpose themselves. There are limits to exposure." As if complementing Luiza's and Débora's opinions, André (37, GK, lawyer, RJ), stated that location sharing goes beyond these limits because "it is more dangerous by nature". This was also the reason why Marcos (36, PRO, systems analyst, RJ) declared: "[Sharing location] is giving your life to others on a platter" and, thus, summarized most non-users' viewpoints.

Users. The analysis of the participants' interviews showed that those who used Foursquare derived pleasure from playing a game of winning points and becoming mayors of a venue (if they had enough points) and/or were attracted by discounts or rewards offered by a number of establishments (mainly abroad). Cláudia (23, GK, photographer, RJ) made it clear that she enjoyed it because she liked taking part in a game in which "you score points and can become 'mayor' of different places". Jorge (33, GK, lawyer, RJ) revealed to take satisfaction in the game's "system of winning badges, points...". Other participants were interested in getting rewards or discounts. Paulo (34, PRO, journalist, RJ) generally uses Foursquare abroad. He was gratified when, in the US, he "checked in a restaurant and got a free dessert". Henrique (36, GK, airline pilot, RJ) was also happy to receive discounts for check-ins abroad: "I checked in a restaurant and got a discount of U\$2,00 (...) I checked in Sport's Authority and received a 25\% discount". At least abroad, discounts and rewards seem to be good incentives for them. In Brazil few establishments offer them.

One would have thought that Foursquare users would not be worried about the dangers of location sharing expressed by non-users. Surprisingly, however, potential risks to safety were mentioned by all of them. Also, much in the same way as non-users, they alluded to several crimes that can be perpetrated on the basis of users' publicized location information. Ronaldo (38, PRO, journalist, RJ), for instance, admitted that a criminal could use the information he shares on Foursquare to break into his house because such an individual would know he wasn't home if checked in elsewhere. Others, such as Paulo (34, PRO, journalist, RJ) revealed a similar perception. Paulo declared that someone "could use [the information about his location] to plan a robbery, a 'lightning-kidnapping' [when a victim is abducted and forced to withdraw money at an ATM] or FORGE a kidnapping [to ask for ransom]".

It follows that they used Foursquare in spite of their own fears. How did they overcome the latter? According to their reports, they took precautions. Thiago (35, PRO, systems analyst, RJ), for instance, said that he "only added $100 \%$ reliable friends [to Foursquare]". Ronaldo (38, PRO, journalist, RJ) did something similar. He said he "liked [location] to be privileged information for only the closest friends, people I trust". Another kind of precaution consisted in checking in only in public places (bars, beaches, movie theaters...). For fear, these users had never checked in home. Marta (30, ELU, teacher, RJ) explained why: "To give my address and warn people I am home is too much! It is not safe in our city". Cláudia (23, GK, photographer, RJ) had the same opinion. When asked whether she had ever checked in home, she exclaimed: "Never! I think it is dangerous, very dangerous... (...) It doesn't matter whether you have fences, safe doors and a doorman. (...) these doors can be opened by danger!"

Several interviewees also made a point of emphasizing that taking precautions is not being paranoid because dangers are real and not imaginary. In their view, such measures are necessary to protect themselves in the violent environments they live in. Thiago (36, PRO, systems analyst, RJ), for instance, declared: "I don't think this is paranoia", while Jorge (33, GK, lawyer, RJ), said "I'm not this paranoid". But it was Henrique (36, GK, airline pilot, RJ) who better expressed what they and others meant. According to him, 
precautionary measures are necessary and "super automatic" for anyone who lives in a violent city. He pointed out that considering them paranoid would be akin to saying "that I am paranoid when I cross the street because I look left and right". More interestingly, he affirmed that, because he is carioca [inhabitant of Rio], he has "built-in habits of personal security" and added: "if people bump into me I check my wallet/ I always lock the car/ I pay attention to my surroundings/ everything automatically/ I joke that this is part of being a carioca".

\section{Results of the Intra-Participants' Analysis}

Intra-participants' analysis only confirmed that which was already evident in the inter-participants' one: the same dilemma was present in the discourse of all interviewees, irrespective of their being Foursquare users or non-users. On the one hand, they all considered Foursquare interesting because it allows friends to be located, makes it possible for users to get discounts and prizes, or simply offers a new game to play. On the other hand, however, all interviewees mentioned dangers associated to the use of this LBSN. As it was shown in the previous sections, even though no questions about risks, dangers or fears were asked (they were not part of the interview schedule), all participants revealed to be fearful of the crimes that can be committed (and have in fact been so) based on location shared by users. The difference between non-users and users lay in how they solved the dilemma. Non-users solved it by giving in to fear and not using this LBSN. Users, however, solved it by adopting protective measures. Fears, though, were present in every participant's interview.

\section{Discussion}

One cannot say that those who participated in the above described study had a dystopian view of Foursquare and other LBSNs. Their reactions to the latter seem to have been dictated by the violent contexts they live in. Danger and violence are part of daily life in the cities they inhabit. Both Rio de Janeiro and São Paulo are marked by rich and poor living side by side and, as a result, by constant thefts, robberies, kidnappings and killings. As it was the respondents' case, in order to guard their personal safety, the inhabitants of these cities have developed a number of precautions that do not refer to any imagined state of affairs, but to a very real one as they themselves made a point of emphasizing.

They take protective measures when moving about the city and they also do so when they are online. Online, the precautions they take are directly linked to some of the strategies developed by low-income Brazilians to gain access to mobile devices and services, which are very expensive in the country. The dissemination of access to mobiles among the members of the low-income strata of the population (by legal or illegal means), despite having promoted social inclusion, has also had an undesirable result. Incarcerated prisoners have gained access to these devices (which are introduced in prisons in a variety of ways) and have started to command organized crime from inside their cells (Costa, 2009; Pinto, 2008; Souza e Silva et al., 2011).

A study carried out by Souza e Silva et al. (2011) is particularly relevant to the present discussion. Low-income people from favelas who participated in it provided these researchers with insiders' knowledge about one particular kind of mobile - the diretão - which may account at least partially for the above presented results. Diretão is a special SIM card illegally obtained with the help of service provider employees. It allows the user to call anywhere in the world for three months free of costs. Calls must be short so that cell position cannot be identified by the provider and the phone disabled. Souza e Silva et al.'s interviewees reported the diretão is commonly used by imprisoned drug traffickers to stay in touch with the outside world and coordinate criminal actions. In fact, it is by means of the diretão that prison inmates commit many of the crimes mentioned by the participants.

Souza e Silva et al. interpret their findings based on Bar, Pisani, and Weber (2007) framework of technological appropriation. The latter view the overall process of technology evolution as a three-step cyclical process, successively proceeding through phases of adoption (when users decide to employ a new technology to support their daily activities), appropriation (when they experiment and modify its features to better adapt the device to their needs) and re-configuration (when a substantial transformation of the technology is made, resulting in the production of a new platform).

Inspired by Latin American colonization and its history of different kinds of appropriation of things, technologies and ideas, Bar et al. (2007) identify three appropriation modes in regard to mobile technology: (a) baroque layering (all kinds of personalization of the phone), (b) creolization (recombination or reprogramming of the technology), and (c) cannibalism (hacking and/or subverting the uses the technology was designed for). In this order, these modes represent increasing degrees of power contestation by users and growing challenges to the established structure.

Souza e Silva et al. (2011) were able to recognize a few instances of cannibalism in their study. The use of diretão, however, was not interpreted as cannibalism in the context of their investigation because there is no hacking of the technology "in ways that are meant to defeat the provider's control and come in direct conflict with the provider's interest" (Bar et al., 2007, p. 35). They do, however, go beyond what happens in regard to technology and claim that the tensions between users and providers also mirror the power relationships between low- and high-income populations. This is exactly where their work seems to provide subsidies to interpret the results of the present study. The argument about to be to put forth is simultaneously technological and social in nature because technologies are both produced and used by people in one or another sociocultural context. It can be expressed as follows. 
As far as the use of smartphones is concerned, the results of the present study suggest that the interviewees have not gone past Bar et al.'s adoption stage in their use of LBS. The latter were already part of all participants' routines (to find their way, monitor exercises, choose restaurants), but no signs of appropriation could be detected in their use. LBSNs, though, presented a radically different picture. They were part of the routine of only four participants who used them regularly, but they also seemed not to have gone past the adoption stage. As far as the others were concerned, however, there were clear instances of what Carroll, Howard, Vetere, Peck, and Murphy (2001) have described as failure to appropriate (when a user decides not to adopt or explore the capabilities of a technology or to evaluate it) and also of disappropriation (when a user evaluates a technology only to later reject it).

Failure to appropriate and disappropiation appear to be rather uncommon reactions mainly when savvy users of DICTs such as the participants of this investigation are concerned. Yet, as it was previously shown, although all of these participants considered the LBSN (Foursquare, in their case) technology interesting, most of them failed to appropriate it. Some made only sporadic use of it failing to explore most of its features while others did not even join it. The best example of failure to appropriate is that of Eduardo, the user who had 11,000 followers on Twitter and had not even tried Foursquare. As to disappropriation, it has already been mentioned that four interviewees joined Foursquare and quit it after a while.

It can be argued that Souza e Silva et al.'s (2011) observation that the tensions between users and providers mirror the power relationships between low- and high-income populations can be expanded to include the tensions between peaceful law-abiding citizens and criminals. As Bar et al. (2007) claim, the appropriation process is fundamentally political in that it is a struggle for power and, consequently, so must be failure to appropriate or disappropriation.

At least in what concerns the present study, there is a strong possibility that both failure to appropriate and disappropriation constituted one of the direct contestations of power Bar et al. allude to. Only, in this case, it was a direct contestation, on the part of users, not of the power of the providers of technology but of the power of organized crime. And this happened because people know that imprisoned criminals use diretões and other cell- or smartphones and are, thus, made capable of commanding criminal actions and disseminating fear. Bar et al. do characterize this as a form of cannibalism and exemplify it by quoting the use of cell phones by the São Paulo's Primeiro Comando da Capital (PCC) to direct criminal actions from within prison cells in 2006.

This contestation, it must be clear, may take the form of sheer rejection of location-disclosure to others, as was the case for most participants in the present study. The populations of Rio de Janeiro and São Paulo may not have the power to confront criminals directly. Nevertheless, they have the power to reject the use of a technology that can provide the latter with useful information.

\section{Final Considerations}

History teaches that the emergence of radically new technologies is usually accompanied by fears, many of which stem from dystopian views of the undesired changes they introduce in people's lives. People's resistance to a given technology, however, is not manifested in the same way in different societies because fears are context-tied. They feed on pre-existing anxieties and concerns which may vary from culture to culture.

This paper examined what happened in the case of telecommunication technologies, both old and recent. In order to do so, it tried to distinguish those reactions which are clearly dystopian from those which are realistic. Such a distinction was once more shown to be historically and/or culturally determined. One can say that the fears provoked by the invention of the telephone were unfounded, and, therefore, dystopian. The same can be said about the diffusion of the Internet, whose effects were thought to be even more drastic than those of the telephone. Cell phones were not seen as radically new and, consequently, did not cause any uproar. But what can be said about smartphones and, mainly, about their locative capabilities? What contributions has this study provided for the understanding of the complex reactions they have generated?

Its main contribution is to show that the Brazilian men and women who participated in the above reported investigation (and represent many others who were not included in the sample) did not seem to have a dystopian view either of smartphones or of their locative capabilities. They did not see them as generating a pervasive bleak reality as the dictionary definition of dystopian would require (McKean, 2005).

There were, however, important differences between LBS and LBSNs. The participants in this study were certainly not afraid of disclosing their location on LBS applications. Nevertheless, they reacted differently to location-disclosure on network environments because this disclosure is more sensitive (or revealing) both in Brazil and in other countries. Cultural differences account for the different manifestations of such sensitivity. In countries like the USA, Canada and the United Kingdom, as previously discussed, the main fears are associated to privacy, surveillance and control. In Brazil, however, such fears do not seem to be active. The interviewees in the study being reported were people who, because of their proximity to technology would be the most unlikely to be afraid of a technological development. Even so, they often spontaneously referred to their fears that, once disclosed, location information could end up in wrong hands (i.e. in the hands of criminals) and put them in harm's way.

This is not a dystopian reaction for people who, like the participants of this study, live in violent cities like Rio and São Paulo where organized crime is commanded from prison with the aid of mobile devices. In fact incarcerated prisoners from different Brazilian states have been shown not only to place and receive calls, but also to update their 
profiles on social networks such as Facebook (Anzoategui \& Dalavechia, 2013; Guerra, 2013). If they use Facebook on the smartphones available to them, they can probably also access to LBSNs. This possibility probably lies beneath the behavior of the men and women who participated in this study. It must be reminded that most of them preferred not to put safety at risk by disclosing their whereabouts on these networks. Judging from the incipient use of LBSNs in Brazil, it seems likely that this is true of many more Brazilian smartphone users. Thus, another contribution of the present study was to show that being considered interesting is not sufficient for a technology to be adopted. A violent social context, such as that of Brazilian metropolises, can also influence whether or not such a technology is going to be used.

These are, however, preliminary results which need further investigation. Smartphones and location awareness have just started to disseminate in the country. Therefore, no one can tell what will happen after these initial stages are over. It remains to be seen what effects these technologies will have upon average users who are generally not so close to technology as the ones in the present study. It is very likely that new patterns of use and maybe even new fears will emerge.

\section{References}

Anzoategui, K., \& Dalavechia, N. (2013, 13 de abril). Preso atualiza rede social e posta fotos de perfumes e dinheiro. O Paraná. Retrieved from http://www.oparana.com. br/policia/preso-atualiza-rede-social-e-posta-fotos-deperfumes-e-dinheiro-29664/

Bar, F., Pisani, F., \& Weber, M. (2007, Abril). Mobile technology appropriation in a distant mirror: Baroque infiltration, creolization, and cannibalism. Paper presented at the Seminario sobre Desarrollo Económico, Desarrollo Social y Comunicaciones Móviles en América Latina, Buenos Aires, Argentina.

Bauman, Z. (2003). Liquid love: On the frailty of human bonds. Cambridge, United Kingdom: Polity Press.

Baym, N. K. (2010). Personal connections in the digital age. Cambridge, United Kingdom: Polity Press.

Brasil já possui 253 milhões de celulares ativos. (2012, May 17). Retrieved from http://www.adnews.com. br/tecnologia/brasil-ja-possui-253-milhoes-decelulares-ativos

Carroll, J., Howard, S., Vetere, F., Peck, J., \& Murphy, J. (2001). Identity, power and fragmentation in cyberspace: Technology appropriation by young people. Proceedings of the Australasian Conference on Information Systems, $12,95-102$.

Castells, M. (2003). Internet e sociedade em rede. In D. Moraes (Org.), Por uma outra comunicação: Mídia, mundialização cultural e poder (pp. 255-287). Rio de Janeiro, RJ: Record.
Consolvo, S., Smith, I. E., Matthews, T., LaMarca, A., Tabert, J., \& Powledge, P. (2005). Location disclosure to social relations: Why, when \& what people want to share. Proceedings of the SIGCHI conference on human factors in computing systems, 81-90.

Costa, C. T. (2009). Sobre o medo em São Paulo: Ainda o espetáculo. Revista USP, (80), 98-110.

De Gournay, C. (2002). Pretense of intimacy in France. In J. E. Katz, \& M. Aakhus (Eds.), Perpetual contact: Mobile communication, private talk, public performance (pp. 193-205). Cambridge, United Kingdom: Cambridge University Press.

Eco, U. (1996). From internet to Gutenberg: A lecture presented at the Italian Academy for Advanced Studies in America. Retrieved from http://www.iisalessandrini.it/ progetti/studenti/frusmesa/inglese/eco.htm

Fischer, C. S. (1992). America calling: A social history of the telephone to 1940. Berkeley, CA: University of California Press.

Gordon, E., \& Souza e Silva, A. (2011). Net locality: Why location matters in a networked world. Chichester, United Kingdom: Wiley-Blackwell.

Greenfield, D. (1999). Virtual addiction: Help for netheads, cyberfreaks, and those who love them. New York, NY: New Harbinger.

Guerra, R. (2013, April 19). Tira foto no presídio pra postar no Facebook. Diário de Pernambuco. Retrieved from http://blogs.diariodepernambuco.com.br/ segurancapublica/? $\mathrm{p}=3607$

Junglas, I. A., \& Watson, R. T. (2008). Location-based services. Communications of the ACM, 51(3), 65-69. doi: $10.1145 / 1325555.1325568$

Katz, J. E., \& Aakhus, M. (Eds.). (2002). Perpetual contact: Mobile communication, private talk, public performance. Cambridge, United Kingdom: Cambridge University Press.

Kim, S. D. (2002). Korea: Personal meanings. In J. E. Katz, \& M. Aakhus (Eds.), Perpetual contact: Mobile communication, private talk, public performance (pp. 63-79). Cambridge, United Kingdom: Cambridge University Press.

Kraut, R., Patterson, M., Lundmark, V., Kiesler, S., Mukophadhyay,T.,\&Scherlis, W.(1998). Internetparadox: A social technology that reduces social involvement and psychological well-being? American Psychologist, 53(9), 1017-1031. doi:10.1037/0003-066X.53.9.1017

Lemos, A. (2010). Mídias locativas e vigilância. Sujeito inseguro, bolhas digitais, paredes virtuais e territórios informacionais. In F. Bruno, M. Kanashiro, \& R. Firmino (Eds.), Vigilância e visibilidade: Espaço, tecnologia e identificação (pp. 61-93). Porto Alegre, RS: Sulina.

Ling, R. (2004). The mobile connection: The cell phone's impact on society. San Francisco, CA: Morgan Kaufman.

Maxwell, J. A. (2005). Qualitative research design: An interactive approach. Thousand Oaks, CA: Sage. 
McKean, E. (Ed.). (2005). The new Oxford American dictionary (2nd ed.). New York, NY: Oxford University Press.

Michael, K., Perusco, L., \& Michael, M. G. (2006, October). Location-based services and the privacy-security dichotomy. Proceedings of the International Conference on Mobile Computing and Ubiquitous Networking, 3, 91-98.

Nicolaci-da-Costa, A. M. (2002). Internet: A negatividade do discurso da mídia versus a positividade da experiência pessoal. A qual dar crédito? Estudos de Psicologia, 7(1), 25-35. doi:10.1590/S1413-294X2002000100004

Nicolaci-da-Costa, A. M. (2004). Impactos psicológicos do uso de celulares: Uma pesquisa exploratória com jovens brasileiros. Psicologia: Teoria e Pesquisa, 20(2), 165-174. doi:10.1590/S0102-37722004000200009

Nicolaci-da-Costa, A. M. (2005). Sociabilidade virtual: Separando o joio do trigo. Psicologia \& Sociedade, 17(2), 50-57. doi:10.1590/S0102-71822005000200008

Nicolaci-da-Costa, A. M. (2007). O campo da pesquisa qualitativa e o método de explicitação do discurso subjacente (MEDS). Psicologia: Reflexão e Crítica, 20(1), 65-73. doi:10.1590/S0102-79722007000100009

Nicolaci-da-Costa, A. M., Romão-Dias, D., \& Di Luccio, F. (2009). Uso de entrevistas on-line no método de explicitação do discurso subjacente (MEDS). Psicologia: Reflexão e Crítica, 22(1), 36-43. doi:10.1590/S0102-79722009000100006

Nisbet, R. A. (1966). The sociological tradition. New York, NY: Basic Books.

Our mobile planet: Brazil - Understanding the mobile consumer. (2012). Retrieved from http://www. mmaglobal.com/files/Brazil_English.pdf

Pellanda, E. C. (2011). A conexão entre lugares e espaços proporcionada pela Rede Foursquare. Intexto, 1(24), 164-175.

Pinto, S. G. (2008). A polêmica dos telefones no interior dos presídios. Revista Factu Jurídica, 8(8), 19-30.

Sennett, R. (1998). The corrosion of character: The personal consequences of work in the new capitalism. New York, NY: W.W. Norton.

Sousa, P. V., \& Cunha, R. E. S. (2012). Entre o ser e o estar: A representação do eu e do lugar no Foursquare. In J. C. Ribeiro, T. Falcão, \& T. Silva (Orgs.), Mídias sociais: Saberes e representações (pp. 31-47). Salvador, BA: EDUFBA.

Souza e Silva, A., \& Frith, J. (2012). Mobile interfaces in public spaces: Locational privacy, control, and urban sociability. New York, NY: Routledge.

Souza e Silva, A., Sutko, D. M., Salis, F., \& Souza e Silva, C. (2011). Mobile phone appropriation in the favelas of Rio de Janeiro, Brazil. New Media \& Society, 13(3), 411-426. doi:10.1177/1461444810393901

Tsai, J. Y., Kelley, P. G., Cranor, L. F., \& Sadeh, N. (2010). Location-sharing technologies: Privacy risks and controls. I/S: A Journal of Law and Policy for the Information Society, 6(2), 119-151.
Young, K. S. (1998). Caught in the net: How to recognize the signs of the internet addiction and a winning strategy for recovery. New York, NY: John Wiley \& Sons.

Zago, G. S., \& Rebs, R. R. (2011). Usos e apropriações do Foursquare no Brasil: Apontamentos para discussão. Revista Nexi, 1(1). Retrieved from http://revistas.pucsp. br/index.php/nexi/article/view/3312/4564

Zickuhr, K. (2012). Three-quarters of smartphone owners use location-based services. Retrieved from http://www. pewinternet.org/Reports/2012/Location-based-services. aspx

Ana Maria Nicolaci-da-Costa is an Associate Professor at the Departamento de Psicologia of the Pontifícia Universidade Católica do Rio de Janeiro.

Mariana Santiago de Matos-Silva holds a Ph.D. from the Graduate Program in Clinical Psychology of the Pontifícia Universidade Católica do Rio de Janeiro.

Received: Oct. $23^{\text {rd }}, 2012$

$1^{\text {st }}$ Revision: May. $3^{\text {rd }}, 2013$

$2^{\text {nd }}$ Revision: Sep. 13 $3^{\text {th }}, 2013$

Approved: Oct. $28^{\text {th }}, 2013$

How to cite this article:

Nicolaci-da-Costa, A. M., \& Matos-Silva, M. S. (2014). Smartphones and location awareness in Brazil: Users' reactions. Paidéia (Ribeirão Preto), 24(57), 115-123. doi:10.1590/1982-43272457201414 


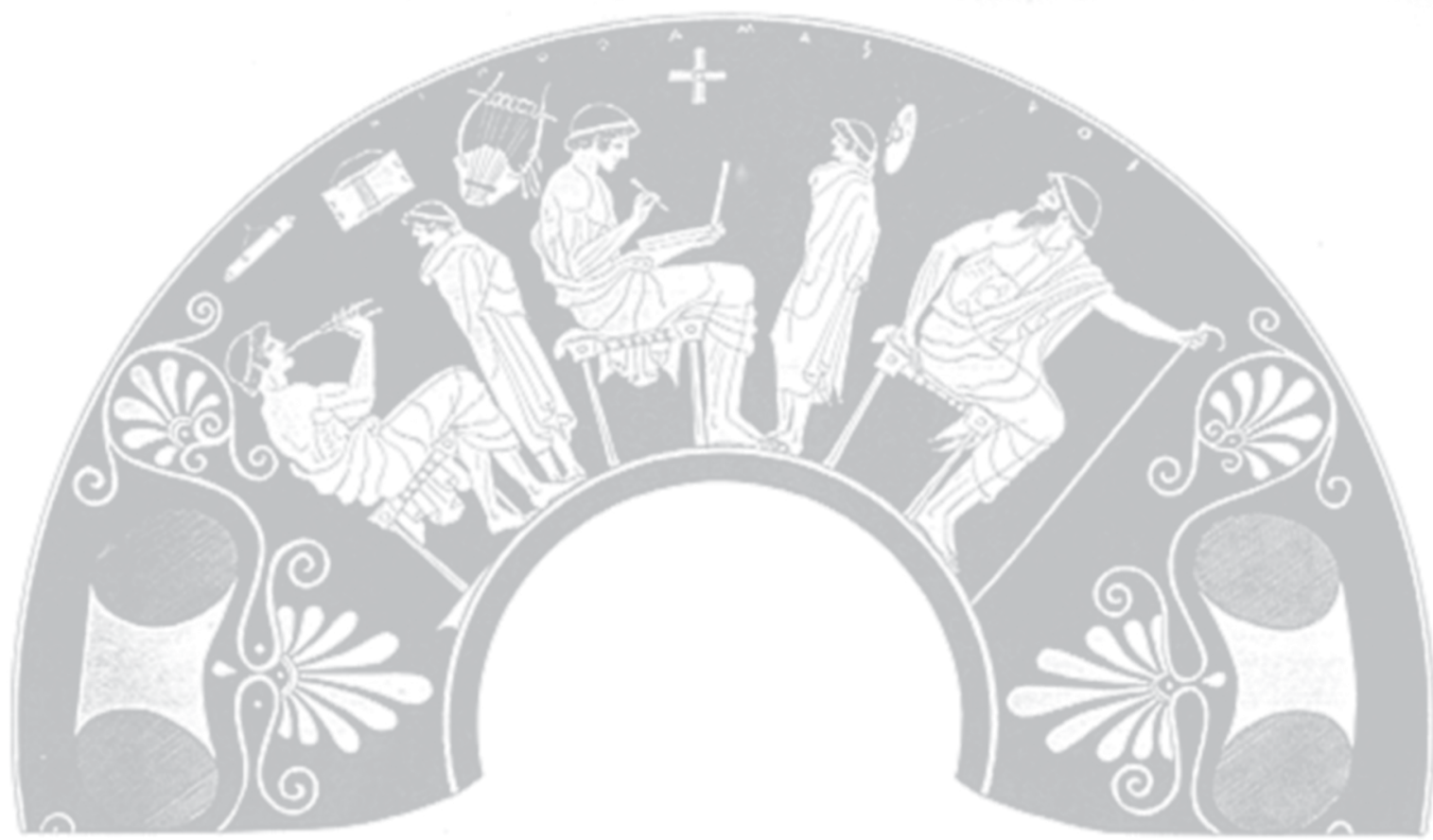

